Vietnam Journal of Mechanics, VAST, Vol. 28, No. 1 (2006), pp. 28-34

\title{
ADSORPTION PROCESS ON FIXED BED COLUMN IN RICH ORGANIC WASTEWATER TREATMENT- EXPERIMENTAL STUDIES AND NUMERICAL SIMULATION
}

\author{
Nguyen Hong Khanh, Nguyen Viet Hoang \\ Institute of Environmental Technology \\ Vietnamese Academy of Science and Technology
}

\begin{abstract}
None axially dispersed plug flow model (NADPF) was applied to simulate adsorption process on fixed bed column. To determine model input parameters and verify the model, isotherm curve, solid diffusion coefficient $\left(\mathrm{D}_{s}\right)$ and breakthrough curve have been determined from experiment. Activated carbon SWW 210\&220 was selected as the main adsorbent for research. Wastewater of Minhkhai Textile Company is the sample used in experiment study. According to isotherm function, textile wastewater is poorly adsorbed into SWW210\&220. Kinetic data also show that diffusion step of textile wastewater is very slow $\left(\mathrm{DS} \sim 1.31 * 10^{-13} \mathrm{~m}^{2} / \mathrm{s}\right)$. With textile wastewater, NADPF model can be used to simulate adsorption process.
\end{abstract}

Keywords: adsorption, simulation, activated carbon, textile wastewater.

\section{INTRODUCTION}

Adsorption is one of the most important methods used to treat the liquid pollutants, especially the non-biodegradable substances (ex. textile wastewater) [5]. Although, the effect of this method is quite high and it may be applied in many cases in that the conventional methods are difficult to be used [6], its application is still limited. An important reason is high price of the adsorbents. Many researchers have focused on the study for finding adsorbents of low price, but these studies are still in laboratory scale. An another approach is to optimize the design and operation of adsorption process. In the framework of fundamental research program in the field of Mechanics, in the Institute of Environmental Technology, Vietnamese Academy of Science and Technology, series of experiment studies and numerical simulation work on a rich organic wastewater by adsorption process have been realised. The equipment for adsorption is the fixed bed column and Jatest and the adsorbent is activated carbon. The sample in research is wastewater of MinhKhai Textile Company. The aim of this paper is to describe the comparison of the results of experiment and simulation through the two experiments carried out in the lab.

\section{NUMERICAL SIMULATION}

\subsection{Mathematical Model of Adsorption Fixed Bed Column}

None axially dispersed plug flow model (NADPF) was applied to simulate adsorption process on fixed bed column. According to $[4,8]$, this model can be used for simulating the adsorption process of liquid-solid. The model includes two partial differential equations. The equation (2.1) describes the material balance of column, and the equation (2.2) 
Eescribes the accumulation rate of the components in the solid phase with the concept that solid diffusion is of a limited step.

$$
\begin{gathered}
\frac{\partial c}{\partial t}+\frac{\rho}{\varepsilon} \frac{\partial q}{\partial t}+v \frac{\partial c}{\partial x}=0 \\
\frac{\partial q}{\partial t}=\frac{15 D_{s}}{r^{2}}(q *-q),
\end{gathered}
$$

-here: $c$ : pollutant concentration in liquid phase $(\mathrm{mg} / \mathrm{l}) ; D_{s}$ : solid diffusion coefficient $\left(\mathrm{dm}^{2} / \mathrm{h}\right) ; q$ : pollutant concentration in solid phase (mg pollutant per $\mathrm{g}$ activated carton): $q^{*}$ : pollutant concentration in solid phase at equilibrium state (mg pollutant per $\Xi$ activated carbon); $r$ : activated carbon radius $(\mathrm{dm}) ; t$ : time $(\mathrm{hr}) ; v$ : liquid velocity in cilsorption column $(\mathrm{dm} / \mathrm{hr}) ; x$ : axial coordinate; $\rho$ : specific weight of activated carbon ( $\Xi / 1)$; $\varepsilon$ : void fraction.

\subsection{Input parameters of Model}

a. Liquid velocity and technical specifications of activated carbon

Liquid velocity is determined by pump. Technical specification of activated carbon is supported by producer [9].

\section{b. Equation of adsorption isothermal curve $\left(q^{*}\right)$}

In the adsorption liquid-solid process, there are two widespread equations for adsorption isothermal curve that are the equation of Langmuir (2.3) and Fruendlich (2.4). The suitable type of adsorption isotherm equation will be selected by the compatibility with experimental results. From this, value of coefficient $a, b, K$ and $\mathrm{m}$ are also determined.

$$
\begin{gathered}
q *=\frac{a b c}{1+b c} \\
q *=K c^{m}
\end{gathered}
$$

- here: $a, b$ : coefficients determined by experiments; $c$ : pollutant concentration in liquid glise $(\mathrm{mg} / \mathrm{l}) ; K$ : velocity of adsorption process determined by experiments; $m$ : coefficient tetermined by experiments; $q^{*}$ : pollutant concentration in solid phase at equilibrium state (zg pollutant per g activated carbon).

\section{c. Solid diffusion coefficient $\left(D_{s}\right)$}

According to [3], value of $\mathrm{D}_{s}$ is calculated from equation (2.5). It presents the linear --lation between $\mathrm{q} / \mathrm{q}^{*}$ and $\mathrm{t}^{0.5}$ with the slop coefficient of $6\left(\mathrm{D}_{s} / \pi \mathrm{R}^{2}\right)$. Therefore, from the - inetic data, value of $\mathrm{D}_{s}$ can be determined easily.

$$
\frac{q}{q *}=6\left(\frac{4 D_{s} t}{\pi d^{2}}\right)^{0.5}
$$

-here: $q$ : pollutant concentration in solid phase ( $m$ g pollutant per $\mathrm{g}$ activated carbon); $q^{*}$ : I.-ilutant concentration in solid phase at equilibrium state (mg pollutant per $\mathrm{g}$ activated carbon); $D_{s}$ : solid diffusion coefficient $\left(\mathrm{dm}^{2} / \mathrm{h}\right) ; d$ : average diameter of activated carbon (dm); t: time (hr). 


\subsection{Solution Method}

To find out solution for the model (described by equation 2.1 and 2.2), set of partial differential equations is converted to set of ordinary differential equations - ODEs. And after that, ODEs are solved by ODE15s program (MATLAB 7.0). Boundary and initial conditions are included:

Initial conditions: $c(0, x)=q(0, x)=0$;

Boundary conditions: $c(t, 0)=c_{0}$ and $\frac{d c(t, H)}{d x}=0$ ( $H$ is the length of bed).

After solving model with the above boundary and initial conditions, obtained results are concentration distribution in liquid and solid phase in time and length of column.

\section{EXPERIMENT AND RESUTL}

\subsection{Experiment}

The purposes of experiment are to determine input parameters for the model (including isotherm curve and solid diffusion coefficient) and to construct breakthough curve (used for model validation).

\subsubsection{Material and Equipment}

Asorbent for research is activated carbon, commercially named SWW210 \& 220 [9]. Water sample is wastewater of MinhKhai Textile Company. Used equipments are Jartest and fixed bed adsorption column ATA2 (Fig. 1).

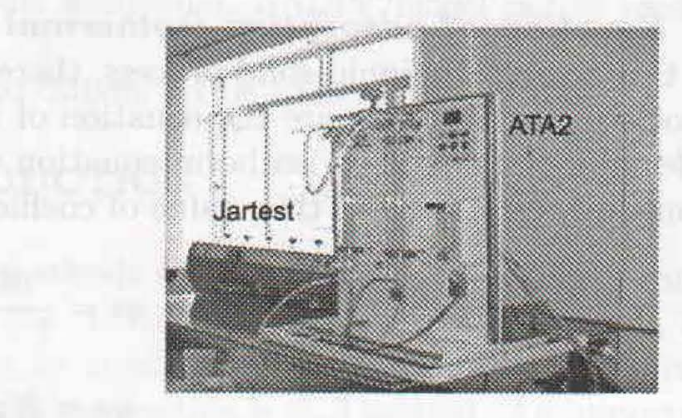

Fig. 1. Jartest and fixed bed

adsorption column ATA2

\subsubsection{Experiment programs}

With the above purposes, two experiment programs were done in laboratory:

Experiment program 1: determining input parameters for model such as: isotherm curve and solid diffusion coefficient (caried out in Jartest equipment).

Experiment program 2: contructing breakthrough curve for model validation (caried out in adsorption fixed bed column ATA2 with down - flow mode).

\subsubsection{Analysis method}

For assessing the treatment efficiency, concentration of COD (chemical oxygen demand - $\mathrm{mg} / \mathrm{l}$ ) is selected for textile wastewater and analyzed according to Standard Method No. $5220 \mathrm{C}[1]$.

\subsection{Experimental results}

\subsubsection{Isotherm curve}

Fruendlich equation is changed to logarithm form and Langmuir one is transfered to inversion form. The relationship between $\log (\mathrm{q})$ and $\log (\mathrm{c})$ or $1 / \mathrm{q}$ and $1 / \mathrm{c}$ has the form 
of line $(y=A x+b$ (Table 1$))$. Value of coefficients in Fruendlich and Langmuir equation is calculated from this.

Table 1. Fitting experimental data with isotherm model

\begin{tabular}{ccc}
\hline Sample & Fruendlich & Langmuir \\
\hline ISOT1 & $\mathrm{y}=5.2279 \mathrm{x}-8.5992\left(\mathrm{R}^{2}=0.917\right)$ & $\mathrm{y}=1.5943 \mathrm{x}-0.0088\left(\mathrm{R}^{2}=0.981\right)$ \\
ISOT2 & $\mathrm{y}=-4.7543 \mathrm{x}-8.7984\left(\mathrm{R}^{2}=0.989\right)$ & $\mathrm{y}=4.9787 \mathrm{x}-0.0176\left(\mathrm{R}^{2}=0.939\right)$ \\
\hline
\end{tabular}

*here: $R^{2}$ is squared value.
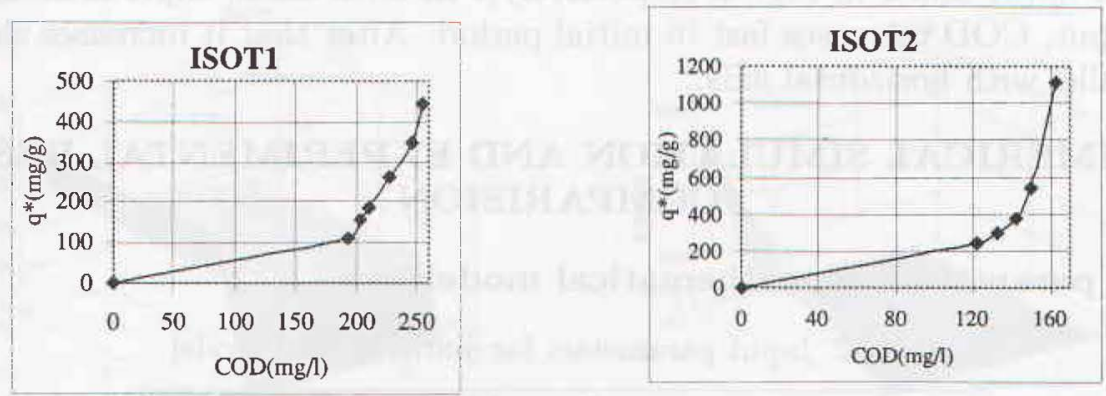

Fig. 2. Relationship between concentration in liquid and solid phase at equilibrium state

Experimental results include two sets of data ISOT1 and ISOT2. These results show thet isotherm curves are concave (Fig. 2); it means adsorption is unfavorable. At small cracentration, isotherm curves are nearly linear (COD $<200 \mathrm{mg} / \mathrm{l}$ with ISO1-Fig. 2 and COD $<150 \mathrm{mg} / \mathrm{l}$ with ISOT2-Fig. 2). Curve slope varies normally. After fitting experimental data with isotherm model (Table 1), the Fruendlich equation is able to represent -rperimental data with reasonable accuracy (equation 3.1 and 3.2). The Langmuir equation cannot be used because in this case value of coefficient $a$ in equation (2.3) is negative.

$$
\begin{aligned}
& \text { ISOT1: } q *=2.5 .10^{-9} \mathrm{COD}^{52279}\left(R^{2}=0.9171\right) \\
& \text { ISOT2: } q *=1.5 .10^{-9} \mathrm{COD}^{4.7545}\left(R^{2}=0.989\right)
\end{aligned}
$$

\subsubsection{Experimental result for determining $\mathbf{D}_{s}$}

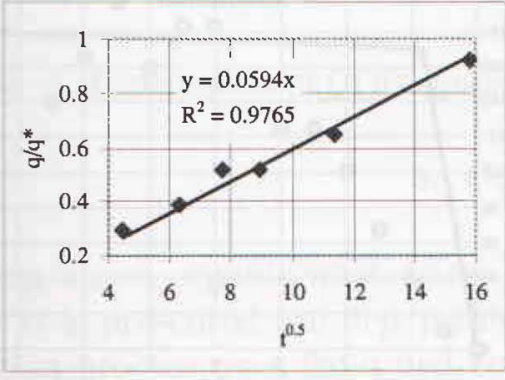

Fig. 3. Relation ship between $q / q *$ and $t^{0.5}$

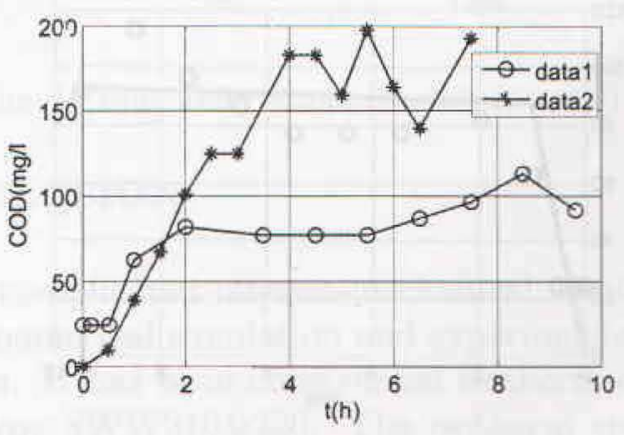

Fig. 4. Breakthrough curve of MinhKhai textile wastewater

In the Fig. 3 there is the result of kinetic experiment for textile wastewater. The whe of solid diffusion coefficient is $1.31 * 10^{-13}\left(\mathrm{~m}^{2} / \mathrm{s}\right)$. For textile wastewater, adsorbents 
are very high molecular species, therefore they are affected strongly by pore's wall when flowing through it. It is the reason why $\mathrm{D}_{s}$ has very small value. It also proves that solid diffusion is the limited step of adsorption process (normally, the value of $\mathrm{D}_{s}$ varies from $10^{-8}$ to $\left.10^{-12} \mathrm{~m}^{2} / \mathrm{s}[8]\right)$.

\subsubsection{Experimental result for constructing breakthrough curve}

Textile wastewater is pretreated by coagulation method (using $\mathrm{Al}_{2}\left(\mathrm{SO}_{4}\right)_{3}$ with coagulant add, polymer A101). Experimental parameters are listed in Table 2 (case 1 and 2 corespond to data1 and 2 in Fig. 4, respectively). In both cases, experimental data show that, at output, COD increases fast in initial period. After that it increases slowly and is nearly parrallel with horizontal axis.

\section{NUMERICAL SIMULATION AND EXPERIMENTAL RESULT COMPARISION}

\subsection{Input parameters of mathematical model}

Table 2. Input parameters for mathematical model

\begin{tabular}{ccc}
\hline Parameter & Case 1* & Case 2* \\
\hline COD $_{0}(\mathrm{mg} / \mathrm{l})$ & 207.23 & 346.98 \\
$\rho(\mathrm{g} / \mathrm{l})$ & 550 & 550 \\
$\varepsilon$ & 0.475 & 0.475 \\
$\mathrm{~d}(\mathrm{dm})$ & 0.009 & 0.009 \\
$\mathrm{v}(\mathrm{dm} / \mathrm{h})$ & 160 & 135 \\
$\mathrm{H}(\mathrm{dm})$ & 2.6 & 2.45 \\
$\mathrm{t}(\mathrm{h})$ & 9.5 & 7.5 \\
$\mathrm{q}^{*}$ & $2.5^{*} 10^{-9} \mathrm{C}^{5.22}$ & $1.5^{*} 10^{-9} \mathrm{C}^{4.75}$ \\
$\mathrm{D}_{s}\left(\mathrm{dm}^{2} / \mathrm{h}\right)$ & $4.716^{*} 10^{-8}$ & $4.716^{*} 10^{-8}$ \\
\hline
\end{tabular}

where, $\mathrm{COD}_{0}$ is $\mathrm{COD}$ of influent $(\mathrm{mg} / \mathrm{l})$.

Input parameters for mathematical model presented by equation (2.1) and (2.2) are given in Table 2

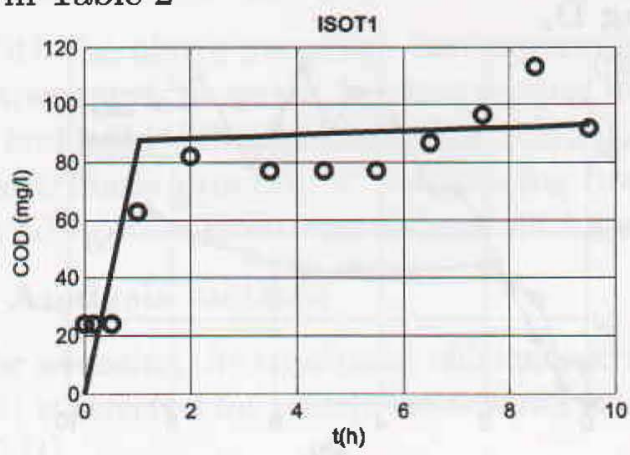

Case 1

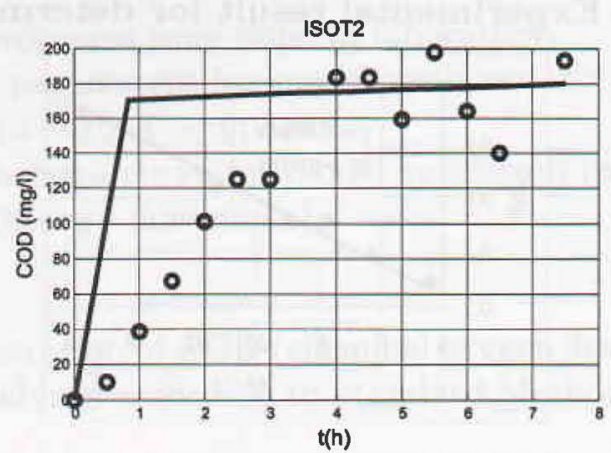

Case 2

Fig. 5. Temporal COD variation at output of fixed bed column (empty point is experimental data and continuous line is model result) 


\subsection{Numerical Simulation results and comparison}

COD behavior by the time at out put of column is shown in fig. 5 . With the input garameters shown in Table 2 (case 1 and 2), model results show that, NADPF model can t- used to predict adsorption process in fixed bed column (Fig. 5).

Distribution of COD concentration in both liquid and solid phase shows that activated cartwon has poor adsorbility with textile wastewater (Fig. 6 and 7). These results suit the istherm curve (adsorption process is unfavorable).
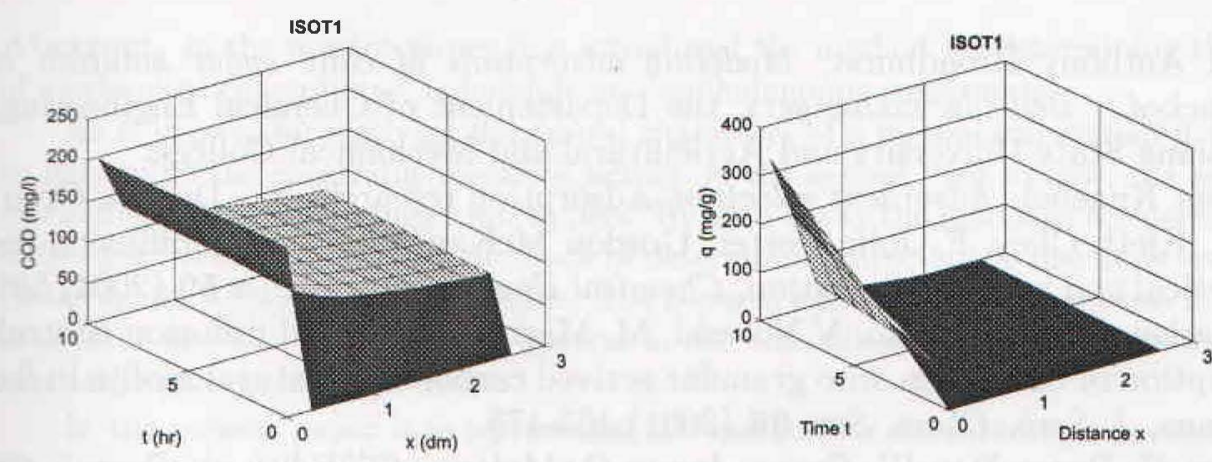

Fig. 6. Distribution of COD concentration in time and column lenghth (Case 1)
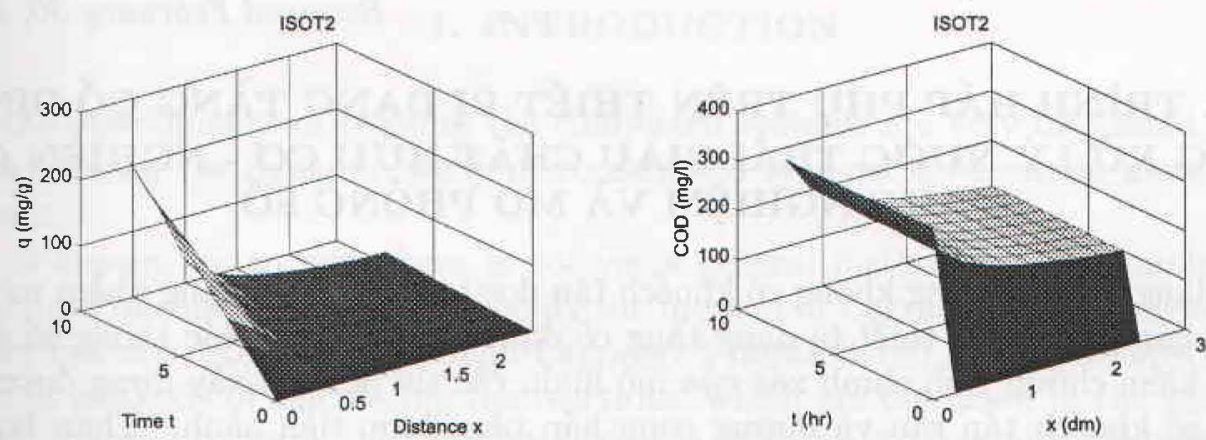

Fig. 7. Distribution of COD concentration in time and column lenghth (Case 2)

\section{CONCLUSION}

Treating a rich organic wastewater is a complicated physico-mechanical problem. In ti:- aner it is presented the first result in numerical simulation and experimental study a: arption process on a fixed bed column. It has been constructed isotherm curve of ter- - rastewater with activated carbon type SWW210\&220. The isotherm curve has ...... Thessed by Fruendlich equation. The solid diffusion coefficient of COD has been detertinsd. None axially dispersed plug flow model (NADPF) can be applied to simulate a-ton process on a fixed bed column

This publication completed with financial support from the National Basic Research Prowa.n in Natural Sciences. 


\section{REFERENCES}

1. Andrew D. Eaton, Lenore S. Clesceri, Arnold E. Greenberg, Mary Ann H. Franson, Standard Method, American Public Health Association, American Water Works Association, Water Environment Federation, 1995.

2. Chi Tien, Adsorption calculation and modeling, Botton: Butterworth - Heinemann, 1994.

3. O. David Cooney, Adsorption Design for Wastewater Treatment, CRC Press LLC, 1999.

4. Hugh Anthony Broadhurst, Modeling adsorption of cane sugar solution colorant in Packed - Bed ion exchangers, the Departement of Chemical Engineering, 2000. Louisiana State University and Agricultural and Mechanical College.

5. S. Kent Knaebel, Adsorbent selection, Adsorption research, Inc, Dublin, Ohio 43016.

6. K. H. Kieth Choy, F. John Porter, Gordon McKay, Film - pore diffusion models analytical and numerical solution, Chemical Engineering Science 59 (2004) 501 - 512.

7. L. Markovska, V. Meshko, V.Noveski, M. Marinkovski, Solid diffusion control of the adsorption of basic dyes onto granular actived carbon and natural zeolite in fixed bed columns, J. Serb. Chem. Soc. 66 (2001) 463-475.

8. Robert H. Perry, Don W. Green, James O. Maloney ( $7^{\text {th }}$ Edition), Perry's Chemical Engineering Handbook, McGraw - Hill.

9. Samchully Carbotech Co., Ltd, Activated Carbon - Products information, 1999.

Received February 30, 2006

\section{QUÁ TRİNH HẤP PHỤ TRÊN THIẾT BỊ DẠNG TẦNG CỐ DỊNH TRONG XỬ LÝ NƯỚC THÀI GIÀU CHẤT HỰ̂U CƠ - NGHIÊN CỨU THỰC NGHIẸM VÀ MÔ PHÒNG SỐ}

Mô hình dạng đẩy lý tường không có khuếch tán dọc trục được sử dụng nhằm mô phỏng quá trình hấp phụ trong thiết bị dạng tầng cố định. Để xác định các thông số đầu vào cũng như kiểm chứng tính chính xác của mô hình, các thí nghiệm xây dựng đường đẳng nhiệt, hệ số khuếch tán rắn và đường cong hấp phụ được tiến hành. Than hoạt tính SWW210 \&220 là vật liệu hấp phụ chính được sự dụng trong quá trình nghiên cứu. Mẫu nước sử dụng cho quá trình thực nghiệm là nước thải nhà máy dệt Minh Khai. Thông qua phương trình đường đẳng nhiệt hấp phụ, nước thải dệt nhuộm ít được hấp phụ trên than SWW210 \&220. Các số liệu về động học cho thấy giai đoạn khuếch tán của nước thải dệt nhuộm rất chậm (Ds $1.31^{*} 10-13 \mathrm{~m} 2 / \mathrm{s}$ ). Đối với nước thải dệt nhuộm, mô hình NADPF có thể được sử dụng để mô phỏng quá trình hấp phụ. 